\title{
1. Sources and origins of EU sports law
} Stephen Weatherill

\section{INTRODUCTION}

There can be only one place to go to discover the source of EU sports law - the first ruling of the Court of Justice which addressed sport, Walrave and Koch $v U C I^{1}$ in 1974. And yet - that ruling had virtually no practical consequence and, moreover, it is tarnished by its intellectually unhelpful embrace of the 'purely sporting' rule. So we need to look elsewhere for the source of EU sports law, and where better than the ruling in Bosman, ${ }^{2}$ which, 20 years of slumber after Walrave, truly broke the dam and made EU sports law a live discipline with real practical impact in litigation. And yet - Bosman, as a case dealing only with free movement law, did not provide a constitutionally secure basis for mediating the relationship between EU law and claims to sporting autonomy and it too, like Walrave, was contaminated by persisting adherence to the 'purely sporting' rule. So the source of EU sports law might instead be sought in the Court's ruling in Meca-Medina, ${ }^{3}$ in which, jettisoning the abstract notion of a 'purely sporting' rule, it finally adopted a realistic approach to the routine capacity of sporting rules also to exert economic effects and, applying EU competition law, insisted on the importance of conducting a case-by-case inspection of the compatibility of sporting practices with EU law. And yet - even Meca-Medina could not conceal the gaping hole in the EU's legitimacy as a regulator of sport, which is that its founding Treaties do not even mention sport. This changed only as late as 2009, when on the entry into force of the amending Treaty of Lisbon, the EU was finally granted an explicit competence to address sport, Article 165 TFEU. So it is surely this which is the constitutionally genuine source of EU sports law. And yet - how can Article 165 constitute the source of EU sports law given that it

\footnotetext{
1 Case 36/74 Walrave and Koch v Union Cycliste Internationale [1974] ECR 1405.

2 Case C-415/93 Bosman [1995] ECR I-4921.

3 Case C-519/04 P Meca-Medina and Majcen v Commission [2006] ECR
} I-6991. 
post-dates a stream of case law stretching over several decades since Walrave and Koch?

There are imposters here, or at least there are pretenders. Choices need to be made. Let us pursue a balloon debate. All four candidate sources of EU sports law are flying in a hot-air balloon, but it is losing height and we must choose which is the first to be thrown overboard in order to save the remainder. We may need to do the same once we are down to three candidates and again once there are two. We need to decide which is the most important source of EU Sports Law in order to provide a compelling account of the factors that have promoted the development of the discipline.

\section{WALRAVE AND KOCH}

Article 5(1) TEU declares that 'The limits of Union competences are governed by the principle of conferral'. Article 5(2) TEU explains that this means that 'the Union shall act only within the limits of the competences conferred upon it by the Member States in the Treaties to attain the objectives set out therein'. The EU is tethered to a defined mandate, which is that granted by the Member States in approving the Treaties. So, logically and constitutionally fundamentally, the EU may not act in the absence of authorisation provided by the Treaties. Sport was not mentioned at all in the original Treaties which entered into force in the 1950s and in fact sport would remain unmentioned in the Treaties until as late as 2009, when the amendments effected by the Treaty of Lisbon introduced Article 165 TFEU.

So in May 1974 when the Court was for the very first time asked to address questions about EU law's application to sport in a preliminary reference made by a court in Utrecht it might plausibly have denied that the matter fell within the scope of its jurisdiction at all. And had it done so, it would have stopped, or at least delayed, the emergence of EU sports law. But in Walrave and Koch the Court chose to be more forthcoming. 4

The case concerned a requirement introduced by the UCI, cycling's governing body, that with effect from 1973 the pacemaker in the world championships for paced cycling should hold the same nationality as the cyclist. EU law clearly prohibits any discrimination on the basis of nationality: that prohibition was at the time contained in Article 7 EEC,

\footnotetext{
4 Case 36/74 Walrave and Koch v Union Cycliste Internationale.
} 
its successor today is Article 18 TFEU. Walrave and Koch, aggrieved Dutch cyclists, were obviously victims of discrimination on grounds of nationality. The question, however, was whether that discrimination fell within the scope of application of the EU's Treaties. Sport, after all, was not mentioned in the text.

In a formula which is of foundational significance in the emergence of EU sports law the Court declared that: 'Having regard to the objectives of the Community, the practice of sport is subject to Community law only in so far as it constitutes an economic activity within the meaning of Article 2 of the Treaty.' 5

What is today Union law rather than Community law applies to sport only in so far as it constitutes an economic activity, but professional sport is readily found to constitute an economic activity. Sport may not have been explicitly mentioned in the Treaties, but the whole thrust of the Treaties was and is to regulate economic activity and this was enough to provoke the Court into making the constitutionally significant connection between EU law and sport. Here, then, is the source of EU sports law.

However, the finding that EU law applied did not mean that the UCI rule was necessarily unlawful. At this point the Court muddied the waters. The Court rescued the UCI's rule from condemnation pursuant to EU law by stating that EU law's prohibition of nationality-based discrimination 'does not affect the composition of sport teams, in particular national teams, the formation of which is a question of purely sporting interest and as such has nothing to do with economic activity'. ${ }^{6}$ This evidently meant that selection on the basis of nationality for a representative team - in football, in rugby, not only in paced cycling - did not offend against EU law. This is a hugely significant step in the development of EU sports law, because it shows how a foundational value of the EU, the prohibition of nationality-based discrimination, may be applied with sensitivity to the special features of sport, which include matches between international teams. But it is analytically a mis-step. To claim that the formation of national teams is 'a question of purely sporting interest and as such has nothing to do with economic activity' is plain wrong. Players enhance their profile and popularity, and therefore their earning potential, as a result of their exposure as international footballers. Restricting selection for national teams has direct and important economic consequences, and indeed the very background to the litigation proved that. Walrave and Koch themselves obviously suffered financially

5 Ibid., para 4.

6 Ibid., para 8. 
by being restricted to pacing only Dutch cyclists in world championship events. This was precisely why they had brought the matter before a court. ${ }^{7}$ Nationality discrimination defines the very character of international team competition and accordingly it should be permitted by EU law, but it is empty to claim it is a purely sporting matter.

EU sports law began with Walrave and Koch. The Court emphasised the Treaty's broad material scope, which is dictated by emphasis on economic activity, ${ }^{8}$ and this brings sport within its net despite the fact that the Treaty was (until 2009) barren of explicit reference to sport. But groping for rules of 'purely sporting interest' was analytically ill-judged: most sporting rules, including those at stake in the case itself, are also economic in their effects. This, then, is to offer a principled objection to the way the Court framed EU sports law in Walrave and Koch. But there are also practical reasons why the case is deficient. It did not generate interest in using EU law to challenge the autonomy of governing bodies in sport. Walrave and Koch chose not to pursue their complaint further, reportedly as a result of the UCI's threat to withdraw their event from the schedule. ${ }^{9}$ Two years later in 1976 the Court confirmed its approach to nationality-based discrimination in its brief ruling in Donà v Mantero. ${ }^{10}$ But then the flow of case law stopped. From the mid-1970s until the 1990s EU sports law slipped into the shadows, a matter of idiosyncratic academic interest devoid of practical bite. ${ }^{11}$ Sporting autonomy reigned.

\section{BOSMAN}

Bosman by contrast changed (almost) everything. ${ }^{12}$ In its preliminary ruling, delivered in response to questions referred by a court in Belgium, the Court of Justice refused to accept a string of devices that were aimed

\footnotetext{
7 See in particular the Opinion of AG Warner in the case.

8 This was fully appreciated at the time: see G Ubertazzi, 'Le Domaine du Droit Communautaire. A propos de l'arrêt Walrave, Union Cycliste Internationale' (1976) Revue trimestrielle de droit européen (RTDE) 635.

9 G Veth, 'Uitsluiting van buitenlandse Voetballers: Mogelijk Binnen de EEG'? (1978) 53 Nederlands Juristenblad 504.

10 Case 13/76 Donà v Mantero [1976] ECR 1333.

11 The paucity of academic attention is tracked in S Weatherill, 'The Lex Sportiva and EU Law: the Academic Lawyer's Path before and after Bosman' in A Duval and B Van Rompuy (eds), The Legacy of Bosman: Revisiting the Relationship between EU Law and Sport (Asser International Sports Law Series/ Springer 2016), chap 10.

12 Case C-415/93 Bosman.
} 
at excluding the application of EU law to sport, ${ }^{13}$ but then it found space within EU law for recognition of sport's particular characteristics in judging whether particular rules were justified. Bosman is more sophisticated in its detailed reasoning than Walrave and Koch but it shares with that case a readiness to treat economic activity as an adequate reason to subject sport to the requirements of EU law even though the Treaties lacked explicit reference to sport. It then builds a sensitivity to the peculiar characteristics of sport into the interpretation and application of EU law. In the vitally important paragraph 106 the Court stated that:

In view of the considerable social importance of sporting activities and in particular football in the Community, the aims of maintaining a balance between clubs by preserving a certain degree of equality and uncertainty as to results and of encouraging the recruitment and training of young players must be accepted as legitimate.

The Court could not have extracted this perception from the Treaty, because, as has been made clear, the Treaty at the time ignored sport. So this is the Court finding its own way to recognise the particular characteristics of sport in order to embed them into its application of the Treaty rules on free movement. This is foundationally important in the development of EU sports law. Indeed the very nature of EU sports law involves the mediation of the assumptions of EU law - competitive cross-border markets cleansed of nationality discrimination - with the expectations of sporting organisation which include, inter alia, nationallybased league structures. Bosman crafts a model of conditional autonomy at the heart of EU sports law - sporting autonomy is respected on condition that it is shown how and why chosen practices are needed to govern sport. ${ }^{14}$

In Bosman itself the Court concluded that nationality discrimination practised at the time in club football did not carry the same resonance as the nationality discrimination at international level to which it had given the green light in Walrave and Koch, and that therefore it had to be abandoned within European football in application to nationals of EU Member States. The Court refused to accept that a link between a club and a player's nationality was in any sense inherent to the structure of club football. It was led in this direction by a flamboyant Opinion prepared by Advocate General Lenz, who asserted that supporters are

\footnotetext{
13 Ibid., paras 69-104, 115-120.

14 This theme is developed in S Weatherill, Principles and Practice in EU Sports Law (OUP 2017).
} 
primarily attached to their club rather than the background of individual players by recalling footballers who have been especially popular when playing in a country that was not their own. ${ }^{15}$ The Court was more prosaic, but the real interest lies in appreciation that the interpretation and application of EU law required the shaping of an EU view of the character of football, in particular club football, against an entirely barren Treaty background. The Court, tasked with judging whether a practice that falls within the scope of EU law is justified, is forced to behave in a creative manner.

The Court also reached the conclusion that the transfer system from which Bosman had suffered, which prevented a player from making a free choice of a new employer even where his contract had come to an end, was in violation of the Treaty rules on the free movement of persons. The system placed footballers in a different position from ordinary employees in other sectors, whose status depends on contract and is not affected by collectively agreed and enforced arrangements that span the global game. Footballers are less constrained in selling their labour today than before Bosman, though a renovated and slimmed down transfer system survives. ${ }^{16}$

Bosman provided a vocabulary and an opportunity: in stark contrast to Walrave the follow-up was rapid and eager. EU sports law was on the move. But even so Bosman cannot count as the source of EU sports law because it suffers from the same intellectual glitch as Walrave and Koch.

The Court in Bosman, citing and repeating Donà and therefore by implication also the parallel reasoning provided in Walrave and Koch, stated that:

the Treaty provisions concerning freedom of movement for persons do not prevent the adoption of rules or practices excluding foreign players from certain matches for reasons which are not of an economic nature, which relate to the particular nature and context of such matches and are thus of sporting

15 Petar Radenkovic, Kevin Keegan, Eric Cantona, and Jürgen Klinsmann.

16 The governing texts are at http://www.fifa.com/about-fifa/officialdocuments/ accessed 26 Oct 2017. There remain open questions about the compatibility of the system with EU law: see G Pearson, 'Sporting Justifications under EU Free Movement and Competition Law: The Case of the Football Transfer System' (2015) 21 ELJ 220; R Parrish, 'Article 17 of the FIFA Regulations on the Status and Transfer of Players: Compatibility with EU Law' 22 MJ 2 (2015) 22(2) Maastricht Journal of European and Comparative Law 256; and Weatherill (n 14), chap 9. 
interest only, such as, for example, matches between national teams from different countries. ${ }^{17}$

This formula remains as intellectually fragile as when it was introduced in Walrave. True, the reasons may not be 'of an economic nature', but the rules plainly exert economic effects. It is empty to describe them as 'of sporting interest only'. Bosman shares with Walrave and Koch a readiness to integrate the notion that (in short) sport is special into the interpretation and application of EU law but it also shares with it a poorly articulated basis for expressing why that is so.

After Bosman the field of play moved away from free movement law to competition law. Not completely: in Deliège v Ligue de Judo the Court decided that rules governing selection for international competitions had an exclusionary effect on those not chosen but that such a limitation is inherent in the conduct of an international sports event, and so it rebuffed an attempt by a disappointed athlete to rely on EU law governing the free movement for services. ${ }^{18}$ This focus on whether a rule is 'inherent' in sporting organisation was a rather better formulation than that used in Walrave and Koch and Bosman. But in Deliège as in Bosman the Court preferred not to address questions referred to it concerning competition law. This soon became the area of the most intense activity.

\section{MECA-MEDINA AND MAJCEN}

The Commission began to deal with sport on the basis of EU competition law at a relatively early stage. In 1992 it adopted a decision concerning the sale of package tours to the 1990 World Cup held in Italy. ${ }^{19}$ But this was not of high significance. The Commission's ENIC/UEFA decision offers a deeper insight into the Commission's emerging treatment of sporting practices in the light of EU competition law. ${ }^{20}$ In 1998 UEFA adopted a rule which stipulated that no two (or more) clubs participating in a UEFA club competition may be directly or indirectly controlled by the same entity or managed by the same person. ENIC considered that the rule distorted competition by restricting investment in football clubs. This offered a pleasingly simple example of friction between the normal

\footnotetext{
17 Case C-415/93 Bosman, para 127.

18 Cases C-51/96 and C-191/97 Deliège v Ligue de Judo [2000] ECR I-2549.

19 Dec 92/521/EEC Distribution of package tours during the 1990 World Cup OJ 1992 L326/31.

20 COMP 37.806 ENIC/UEFA, IP/02/942, 27 June 2002.
} 
assumptions of EU competition law, which would treat this as a restraint on competition in the market for acquisition of clubs, and the sportspecific concern to eliminate any whiff of match-fixing that would subvert the uncertainty of result that is essential to the very nature of competitive sport. The Commission agreed that in principle the UEFA rule was capable of falling within the scope of what was then Article 81(1), now Article 101(1) TFEU, but, referring to the need to guarantee the integrity of affected competitions, it decided not to pursue the matter further and it rejected ENIC's complaint. ENIC did not pursue the matter either. The Commission's approach is rooted in a model of 'conditional autonomy': the practice fell within the scope of EU law because of its effect on the market for clubs (that is, there is no absolute autonomy for sport from EU law), but autonomy was permitted provided it met the conditions set by EU law which here were attuned to the special sensitivity in sport to achieve a rigorous separation of ownership between clubs that are supposed to be rivals on the pitch.

In ENIC the Commission built its analysis on the Court's ruling in Wouters, delivered in February 2002.21 The factual background in Wouters has nothing to do with sport. But Wouters has established itself as centrally important in the evolution of EU sports law. The Court was asked to consider the compatibility with what is now Article 101 TFEU of a Dutch rule forbidding the creation of multi-disciplinary partnerships involving barristers and accountants. This prevented the emergence of partnerships offering a wider range of services and able to benefit from economies of scale apt to generate cost reductions. The Court emphasised that there were effects restrictive of competition $^{22}$ but it took the view that they did not go beyond what was necessary in order to ensure the proper functioning of the legal profession in the Netherlands. The rules guaranteed the independence and loyalty to the client of members of the Bar as part of a broader concern to secure the sound administration of justice. There was no breach of EU competition law. In short, the question was: is the practice of the legal profession 'special'? The answer: it was. And in ENIC the Commission applied the same model to sport. Asking the same question, it arrived at the same answer. Adopting the language of Wouters, the Commission in ENIC asked whether the consequential restrictive effects of UEFA's rule were inherent in the pursuit of the very existence of credible European football competitions.

\footnotetext{
21 Case C-309/99 Wouters [2002] ECR I-1577.

22 Ibid., paras 94, 109, 110.
} 
They were, and so the UEFA prohibition escaped condemnation pursuant to EU competition law.

It was in Meca-Medina ${ }^{23}$ that the Court got its teeth into the matter. This is the landmark ruling concerning the application of EU competition law to sport but even more so, and the reason it competes for attention as the source of EU sports law, it finally involves the Court shaking off its misguided concern for rules that are 'purely sporting' and instead, and in more intellectually coherent vein, it insists on a case-by-case examination of rules that are typically not only sporting but also economic in their effects.

The case concerned professional swimmers who had failed a drug test administered by the sport's governing body, FINA. As a result they had been banned from competition for a period of two years. The case reached the Court of Justice as a result of the Commission's refusal to pursue a complaint by the swimmers, which was the subject of review by the Court of First Instance, today the General Court, ${ }^{24}$ which, on appeal, reached the Court of Justice.

The Court began by confirming that sport is subject to EU law 'in so far as it constitutes an economic activity'. ${ }^{25}$ It cited both Walrave and Koch and Bosman. The Treaty prohibitions against restrictions on free movement 'do not affect rules concerning questions which are of purely sporting interest and, as such, have nothing to do with economic activity'. ${ }^{26}$ But in Meca-Medina the Court then moved beyond this inadequate formula.

The Court added that even where one finds such a rule, this 'does not have the effect of removing from the scope of the Treaty the person engaging in the activity governed by that rule or the body which has laid it down' ${ }^{27}$ The Court explained that the compatibility of rules with EU competition law cannot be assessed in the abstract. In applying Article 101(1) TFEU, 'account must first of all be taken of the overall context in which the decision of the association of undertakings was taken or produces its effects and, more specifically, of its objectives'; and it 'has then to be considered whether the consequential effects restrictive of competition are inherent in the pursuit of those objectives ... and are

\footnotetext{
23 Case C-519/04 P Meca-Medina and Majcen v Commission.

24 Case T-313/02 Meca-Medina and Majcen v Commission [2004] ECR II-3291.

25 Case C-519/04 P Meca-Medina and Majcen v Commission, para 22.

26 Ibid., para 25.

27 Ibid., para 27.
} 
proportionate to them'. ${ }^{28}$ The Court cited its ruling in Wouters. ${ }^{29}$ This, then, is to import into EU sports law the appreciation contained in EU competition law generally that finding a restriction of competition does not conclude the investigation under Article 101(1). It is to open up the legal assessment of practices that have the effect of restricting competition also to include appraisal of their objective. For sport that means to open up the legal assessment of sporting practices that have the effect of restricting competition also to include appraisal of their sporting objective.

The Court decided that anti-doping rules did not necessarily constitute a forbidden restriction of competition within the meaning of (what is now) Article 101 TFEU, since they were 'justified by a legitimate objective'. ${ }^{30}$ Detailed appreciation of fair procedure and proportionate sanctions would be required but the Court could see no reason to disturb the judgment of FINA that the suspension of the swimmers was necessary for the organisation of the sport. This is consistent with the ruling in Wouters on which the Court placed explicit reliance. It is also comfortably in line with the Court's view in Bosman that the transfer system pursued 'legitimate' objectives and it chimes too with the depiction of selection rules as 'inherent' in the conduct of an event in Deliège $v$ Ligue de Judo, albeit that both those rulings involved free movement law. Meca-Medina nudges free movement and competition law towards convergence in their appreciation that sporting specificity moulds the interpretation and application of the EU's rules.

The transformative significance of Meca-Medina lies in its abandonment of the notion that there is utility in searching for 'purely sporting' rules. Anti-doping rules are plainly sporting rules, for they define the outer limits of permitted competition, but they are economic too, both in their purpose (given that 'clean' sport is more attractive to sponsors and broadcasters) and in their effect (on athletes, whose earning capacity is affected). The Court in Meca-Medina is astute to this. A practice may be of a sporting nature - and perhaps sometimes 'purely sporting' in intent but it must be tested against the demands of EU law where it exerts economic effects. Meca-Medina establishes that few rules are sporting but not also economic in nature and/or effect. The majority of rules are both. This gives realistic shape to the intersection of EU law and 'internal' sports law. This does not subvert the principle of conferral found in

\footnotetext{
28 Ibid., para 42.

29 Case C-309/99 Wouters.

30 Case C-519/04 P Meca-Medina and Majcen v Commission, para 45.
} 
Article 5(1) TEU according to which the EU law operates on the basis of a limited mandate, but rather it is to emphasise how the linkage of that mandate to the economic project of market integration grants the EU legal order a broad scope in practice. But within that broad scope the Court insists on receptivity to the claim that sport is (in short) special, just as in Wouters the administration of justice was treated as special, so that the EU's rules are applied with contextual sensitivity. Specificity is not a reason to grant absolute protection of sporting autonomy from EU law, but appreciation of sport's special features is fed into the analysis in the application and interpretation of EU law. This is the heart of the model according to which EU law grants sporting bodies a conditional autonomy.

The consequence of this approach is a need for a case-by-case examination of the compatibility of sporting practices with the Treaty. ${ }^{31}$ True, this has attracted disquiet from within sport on the basis that it breeds uncertainty and unpredictability. ${ }^{32}$ But intellectually the Court's approach in Meca-Medina is far superior than the contorted claim that 'purely sporting' rules are a useful conceptual category; and the Court is conscientious in ensuring that EU law is open to assessment of the claims by sporting bodies that their practices should be treated as necessary for the organisation of sport.

Meca-Medina is now central to the shape of EU sports law, having ousted the unhappy notion of the 'purely sporting' rule from prominence among the sources of EU sports law. So the European Commission's White Paper on Sport, issued in July 200733 places heavy reliance on the Court's ruling in Meca-Medina, and in fact cites no other decision of the

31 This was noted at the time: see eg S. Weatherill, 'Anti-doping Revisited the Demise of the Rule of 'purely sporting interest'? [2006] European Competition Law Review 645; M Wathelet, 'L'arrêt Meca-Medina et Majcen: plus qu'un coup dans l'eau' [2006/41] Revue de Jurisprudence de Liége, Mons et Bruxelles 1799; A Rincon, 'EC Competition and Internal Market Law: on the Existence of a Sporting Exemption and its Withdrawal' (2007) 3 Journal of Contemporary European Research 224.

32 See eg G Infantino [at the time Director of Legal Affairs at UEFA, now President of FIFA], Meca-Medina: A Step Backwards for the European Sports Model and the Specificity of Sport? UEFA paper 02/10/06, at http://www.uefa. com/MultimediaFiles/Download/uefa/KeyTopics/480391_DOWNLOAD.pdf, accessed 26 Oct 2017; J. Zylberstein, 'Collision entre Idéaux Sportifs et Continges Économiques dans l'arret Meca-Medina' (2007) 48 Cahiers de Droit Européen 218.

White Paper on Sport, COM (2007) 391. 
Court of Justice in its 20 pages of legal analysis. This treats MecaMedina as the purest source of EU sports law!

\section{ARTICLE 165 TFEU}

The problem in the three landmark cases examined above is that all are based on EU internal market law and none - explicitly - is based on sports law. In these decisions the EU reaches sport through conferred competences associated with the internal market which do not mention sport. The examination above makes the case that the Court has been attentive to the sporting context in which it is asked to apply free movement and competition law, but this will not satisfy those concerned to maximise the autonomy of sports bodies and sceptical of the Court's expertise. $^{34}$ There was no explicit basis in the Treaty for the Court to frame its inquiry into nationality rules, the transfer system and antidoping. The Court's case law strains the reach and legitimacy of EU law.

However, as a result of the revisions made by the Treaty of Lisbon with effect from December 2009, the constitutional landscape is radically transformed. Article 6 TFEU declares that the Union shall have competence to carry out actions to support, coordinate or supplement the actions of the Member States in several listed areas, one of which is sport, which appears in Article 6(e) TFEU in the company of education, vocational training and youth. Article 165 TFEU supplies more detail on the nature of this competence. Sport is now mentioned in the Treaties: it is now an area where the EU is authorised to act. This, one might suppose, is the source of EU sports law.

Article 165 TFEU, filleted of content pertaining to education in order to bring into focus what it does for sport, reads:

1. ... The Union shall contribute to the promotion of European sporting issues, while taking account of the specific nature of sport, its structures based on voluntary activity and its social and educational function.

2. Union action shall be aimed at: ... developing the European dimension in sport, by promoting fairness and openness in sporting competitions and cooperation between bodies responsible for sports, and by protecting the

34 See eg R. Subiotto, 'The Adoption and Enforcement of Anti-doping Rules should not be Subject to European Competition Law' [2010] European Competition Law Review 323; D Dixon, 'The Long Life of Bosman - a Triumph of Law over Experience' (2008) 6(2): 3 ESLJ, http://www.entsportslawjournal.com/ articles/10.16997/eslj.60/, accessed 26 Oct 2017. 
physical and moral integrity of sportsmen and sportswomen, especially the youngest sportsmen and sportswomen.

3. The Union and the Member States shall foster cooperation with third countries and the competent international organisations in the field of education and sport, in particular the Council of Europe.

4. In order to contribute to the achievement of the objectives referred to in this Article: the European Parliament and the Council, acting in accordance with the ordinary legislative procedure, after consulting the Economic and Social Committee and the Committee of the Regions, shall adopt incentive measures, excluding any harmonisation of the laws and regulations of the Member States; the Council, on a proposal from the Commission, shall adopt recommendations.

This is the sport-specific competence conferred on the EU. At the level of constitutional principle it is transformative: at last the EU's involvement in sport is explicitly recognised. However, Article 165 is self-evidently not a generous grant of competence to the EU. It is carefully confined in its reach, in particular by permitting legislative action only through adoption of 'incentive measures'. The EU is no sense elevated to a primary position of responsibility in the regulation of sport. The story behind the negotiations that that led to Article 165 is built on the grudging acceptance by sporting bodies that it was politically impossible for them to extract a promise of absolute autonomy from the EU and so instead they preferred the next best solution, which is inclusion within the EU system, but on terms which highlight the claim of sport to deserve special treatment. ${ }^{35}$ This is the gist of Article 165, captured most of all in its insistence that sport has a 'specific nature'. Article 165 exists largely because sports federations grasped from the case law discussed above that a co-existence with the EU was unavoidable and so they sought to impose terms on the nature of that co-existence - that it shall be 'sports-sensitive'.

It follows that Article 165 is constitutionally radical but in substance less remarkable. It provides an explicit orientation for an EU policy on sport and a small budget is attached to its development. This is handled by the Directorate General for Education and Culture within the Commission. ${ }^{36}$ This would have been constitutionally impermissible before 2009. For example, there has existed since 2008 a sectoral committee

35 The full story is told in B García and S Weatherill, 'Engaging with the EU in order to Minimize its Impact: Sport and the Negotiation of the Treaty of Lisbon' (2012) 19 JEPP 238.

36 Its website is at http://ec.europa.eu/sport accessed 26 Oct 2017. 
covering employment in professional football, but this is a product of the 'social dialogue' foreseen by Articles 154 and 155 TFEU: it reaches sport via EU social policy, not as a sports policy per se. ${ }^{37}$ Article 165 opens the door to the EU's direct engagement with sport, but it is calculatedly limited in the scope of its grant of competence. This is manifest in the Commission's report on the implementation of the EU's first Work Plan for Sport, which covered 2011-14. ${ }^{38}$ It describes a strengthened cooperation between the EU and the Member States in line with Article 165 in an effort to develop further the European dimension in sport, and treats the EU's supporting competence in the field as a means to provide 'a valuable framework for all actors to cooperate in a coordinated way and in mutual respect of national and EU competences'. 39 The follow-up Work Plan for Sport to cover 2014-17 is founded on a Council Resolution. ${ }^{40}$ It is similarly marked by promises to work with sports governing bodies and relevant competent organisations at national, European and international levels such as the Council of Europe and the World Anti-Doping Agency (WADA), rather than to claim pre-eminence for the EU. In similar vein an EU Expert Group on 'Good Governance' held its first meeting in December 2011 and in October 2013 the Group adopted Recommendations on the Principles for Good Governance of Sport in the EU. ${ }^{41}$ The intention is not to impose such principles - there would in any event be no competence for such an intervention - but rather to induce better practice.

Moreover there is no hint that Article 165 is apt to alter the trajectory of internal market law. The Court treats Article 165 TFEU as a corroboration of its case law. ${ }^{42}$ This seems compelling. The 'specific nature' of sport recognised by Article 165 is readily understood as a confirmation of the pre-existing model of 'conditional autonomy' developed by the Court over the extended period lasting until 2009 in which sport was not even mentioned in the EU's governing Treaties. The Court's rulings in the landmark cases - Walrave and Koch; Bosman; Deliège; and MecaMedina - are expressions of Article 165 TFEU's direction that the EU 'shall contribute to the promotion of European sporting issues, while

\footnotetext{
37 http://ec.europa.eu/social/main.jsp?catId=480\&intPageId=1848\&langId=en, accessed 26 Oct 2017.

38 COM (2014) 22.

39 Ibid., 2.

40 OJ 2014 C183/12.

41 http://ec.europa.eu/sport/policy/organisation_of_sport/good_governance_en. htm, accessed 26 Oct 2017.

42 Case C-325/08 Olivier Bernard [2010] ECR I-2177, para 40.
} 
taking account of the specific nature of sport'. Article 165 is not tied to either free movement law or to competition law. It should be understood as applying to both, and it promotes the need to interpret them in a convergent manner. In sum, the 'Lisbon vocabulary' serves to re-frame the legal analysis, but the outcome of scrutiny of sporting practices with economic effects in the light of EU law does not change at all.

The principal significance of Article 165 does not lie at the level of detail. Instead its chief significance is that the EU's role in the field of sport is legitimated. Sporting bodies can no longer claim that sport is none of the EU's business. Their aim instead should be to accept that the EU possesses a legitimate role but to seek to steer the EU towards full recognition of sport's particular characteristics. Absolute sporting autonomy is unfeasible; conditional autonomy is the model. It is therefore wise for sporting bodies to seek to work with the institutions of the EU, most of all the Commission, rather than to seek fruitlessly to keep them at arm's length.

Astute sports governing bodies had already grasped this before 2009, propelled by realisation that a strategy of exclusion had been so consistently exposed as unsuccessful before the Court and the Commission. ${ }^{43}$ Since 2009 the patterns of cooperative activity have become more marked. In 2014 the Commission made a Decision adopting an arrangement for co-operation between itself and UEFA. ${ }^{44}$ This asserts 'a common goal to promote and safeguard the values of fairness and openness in sport'. A commitment is made to respect all relevant rules, including competition law. There is nothing particularly surprising about the content of the agreement, the content of which is frankly rather anodyne. The interest lies in its very existence. It demonstrates that dialogue is the envisaged way forward to manage the intersection of EU law and practices pursued in sport. Governance in sports has come to involve a complex network of actors and stakeholders. ${ }^{45}$

A helpfully concrete example is provided by UEFA's Financial Fair Play Regulations (FFP). ${ }^{46}$ The overall intent of FFP is to impose a

43 See in particular B. García, 'UEFA and the European Union: From Confrontation to Co-Operation' (2007) 3 Journal of Contemporary European Research 202.

$44 \mathrm{C}(2014)$ 7378, 14 October 2014.

45 See A Geeraert, J Scheerder and H Bruyninckx, 'The Governance Network of European Football: Introducing New Governance Approaches to Steer Football at the EU level' (2013) 5 Intl Journal of Sport Policy and Politics 113.

46 Available via http://www.uefa.org/protecting-the-game/club-licensing-andfinancial-fair-play/, accessed 26 Oct 2017. 
break-even requirement. Clubs must not spend more than they earn over a defined period, according to a detailed set of intricate rules which include the power to impose sanctions on offending clubs. It is in short a means to suppress 'financial doping'. The legal problem is that this smells suspiciously like an anti-competitive arrangement struck 'horizontally' between parties - clubs - that should be competing with each other. FFP locks all clubs into an agreed restraint on spending, which will, inter alia, reduce spending on players' wages. FFP will also cement in place the advantages enjoyed by the currently dominant clubs in European football by placing high barriers in the path of a smaller club wishing to spend its way to success by attracting outside investment.

It is possible that the arrangements could be saved if, according to the analytical logic considered above in Wouters and applied in MecaMedina, they are shown to be necessary to address particular problems that arise in professional football, most plausibly perhaps that they stop clubs winning trophies through reckless over-spending rather than sporting merit: a subsequent collapse of such a club into administration is small consolation to the club that spent responsibly only to finish runner-up to the financial doper. The legal status of FFP is unclear. ${ }^{47}$ UEFA, however, has shrewdly attempted to avert the need to defend its rules in court. In 2012 a 'Joint Statement' by Commissioner Almunia and Michel Platini, then the President of UEFA, declared that FFP's 'break even' rule is based on sound economic principle and added that its objectives are consistent with EU state aid policy. ${ }^{48}$ The 'Joint Statement' is not legally binding and its reasoning is frankly thin. But its very existence reveals that UEFA and the leading football clubs of Europe have succeeded in getting close to the Commission and securing its approval. The settlement does not exclude that an individual may act as a 'new Bosman' and attack FFP as a breach of EU competition law before

47 For illuminatingly different views see C Davies, 'Labour Market Controls and Sport in the Light of UEFA's Financial Fair Play Regulations' [2012] ECLR 435 (lawful); C Flanagan, 'A Tricky European Fixture: an Assessment of UEFA's Financial Fair Play Regulations and their Compatibility with EU Law' (2013) 13 Int Sports Law Jnl 148 (probably lawful); N Petit, 'Fair Play Financier ou Oligopoleague de Clubs Rentiers?: Eléments d'Analyse en Droit Européen de la Concurrence' (2014), http://papers.ssrn.com/sol3/papers.cfm?abstract_id=2438 399, accessed 26 Oct 2017 (unlawful). See also Weatherill (n 14), chap 10.

$48 \mathrm{IP} / 12 / 264,21$ March 2012. The statement is at http://ec.europa.eu/ competition/sectors/sports/joint_statement_en.pdf, accessed 26 Oct 2017. 
a national $\operatorname{court}^{49}$ but UEFA's cooperation with the Commission has for the time being removed its fears of attack by that institution. The negotiation of the true meaning of Article 165 TFEU seems likely to intensify still further such institutional interaction in the development of EU sports law.

\section{CONCLUSION}

EU sports law is borne aloft by all four of the landmark sources examined in this chapter. To discard any one of the four would radically re-shape - and impoverish - the quality of EU sports law. Walrave and Koch was vital in asserting the broad reach of EU law, catching all practices with economic effects including in sport. Bosman took this further by requiring adaptation of existing sporting practices in the light of the demands of EU law, thereby showing that EU sports law has practical transformative vitality. Meca-Medina gave intellectual weight to the discipline of EU sports law by shifting attention away from the unhelpful category of 'purely sporting' rules and focusing instead on a case-by-case examination that is appropriately infused by sensitivity to sport's peculiar features, and which recognises that most sporting rules that operate in a professional context are also rules that have economic effects. Finally, Article 165 has provided a constitutional foundation for EU sports law, both by providing the vocabulary of the 'specific nature' of sport as a means to package the existing case law concerning the rules of the internal market and to provide a basis for future contribution by the EU to improving sports governance.

These are the sources of EU sports law. Put all four together and there is a developing integrated pattern to EU sports law which, moreover, has real practical significance. This chapter's Introduction suggested a need to decide which is the true source of EU sports law, and to discard from the balloon those that cannot attain the summit. This would harm EU sports law. And happily there is no need to do it. The most remarkable change to the landscape of sport in Europe over the last 30 years has not been caused by the case law of the Court of Justice nor the pattern of EU Treaty amendments. The biggest transformative influence in sport has been the deregulation of the market for rights to broadcast events,

49 An attempt failed in Case C-299/15 Striani v UEFA, URBSFA Order of 16 July 2015 (reference inadmissible). See S Bastianon, 'The Striani Challenge to UEFA Financial Fair Play. A New Era after Bosman or just a Washout?' (2015) 11 The Competition Law Review 7. 
coupled to startling technological advances which have opened up an unimaginably wide range of means to provide such services. Rights to show top-level sport are eagerly sought by broadcasters in order to secure large market shares and the prices paid are commensurate with the ferocity of that demand. Money has cascaded into sport. There is no need to throw any of our candidate sources out of the balloon. EU sports law will continue to be inflated by its earning capacity for some time to come. Let the balloon ride continue. 